\title{
Anarchitextures: Intermedial Encounters On The Screen
}

Ariadne Mikou, University of Roehampton

\begin{abstract}
In this article I draw on architectural and choreographic ways of thinking to discuss how filmed material is transformed through projection and active and mobile spectatorship. Shifting my attention from what is projected to where it is projected, I expand the discourse beyond the single flat cinematic screen. I do this by concentrating on how the projected surface (its placement in space and its assembly with multiple screens) creates social encounters. This study accepts Rosenberg's definition of the screen as "a receptor of an otherwise ephemeral image and which reifies that image in the process of receiving it." ${ }_{1}$ Anarchitextures 2 is a screen-based performance project through which I explored Eisensteinian montage to include a spatial and ambulatory practice. The project speaks to choreographic environments and events that use the screen as a socially engaged practice, and also poses some questions regarding the boundaries that appear to shape the screendance field.
\end{abstract}

Keywords: practice-as-research, intermediality, event-spaces, Tschumi, expanded choreography, haptic materiality, Bruno, montage in space, Eisenstein

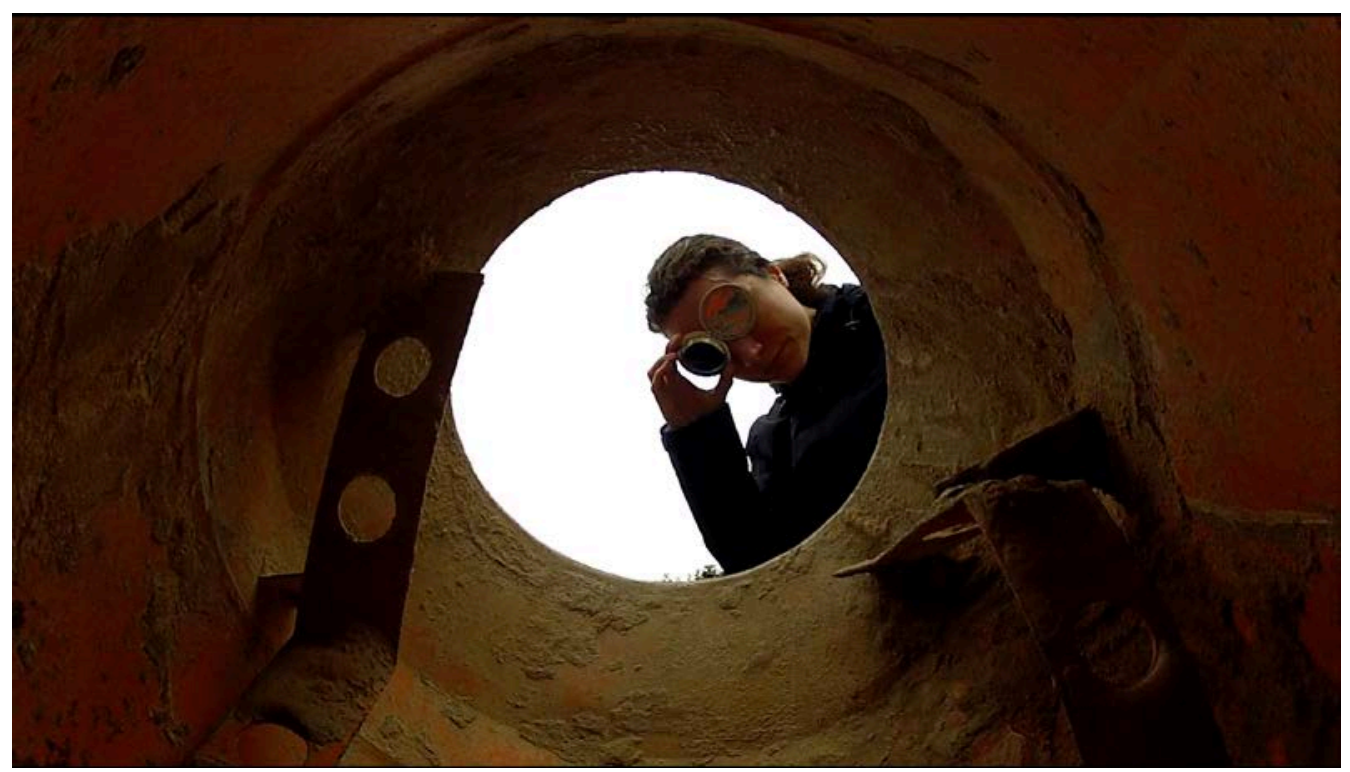

Still image by one of the several clips projected during Anarchitextures. Credit: Author. Link to video: https://vimeo.com/170866405 
Lights at a low intensity inside Michaelis Building, a black box theatre located in South West London. Around 100 rectangular cardboard boxes painted with blackboard paint and covered with a thin layer of cement form vertical walls on the top of a large architectural diagram designed by white tape on the black floor of the stage. It is a copy of the architectural plan of Robin Hood Gardens Estate, a twin social house in East London that is currently in a state of impending demolition. Moving images of a performer that have been recorded while she was moving around the two weathered buildings of the Estate, are projected on the light and able-to-be-divided walls of the set design. Gradually throughout the day, the audience enters the environment and begins to displace the boxes, allowing the space to transition from detailed clarity to chaos. Because of the displacement of the cubes, the projected image fragments, folds, gains three-dimensionality, or disappears from the textured cubes to appear differently on other non-reflective surfaces of the surrounding space. Throughout the alteration of the environment the white taped lines of the traced buildings remain intact while the pre-constructed environment evolves into a demolished landscape. In the backdrop, a repetitive clip depicts the continuous circular motion of a concrete mixer. The clip suggests an exit from the darkness of the theatre to the natural light of the sky, but the incoming light remains overshadowed by a pair of eyes, which look from the opening of the womb-like concrete machine into the world of theatre.

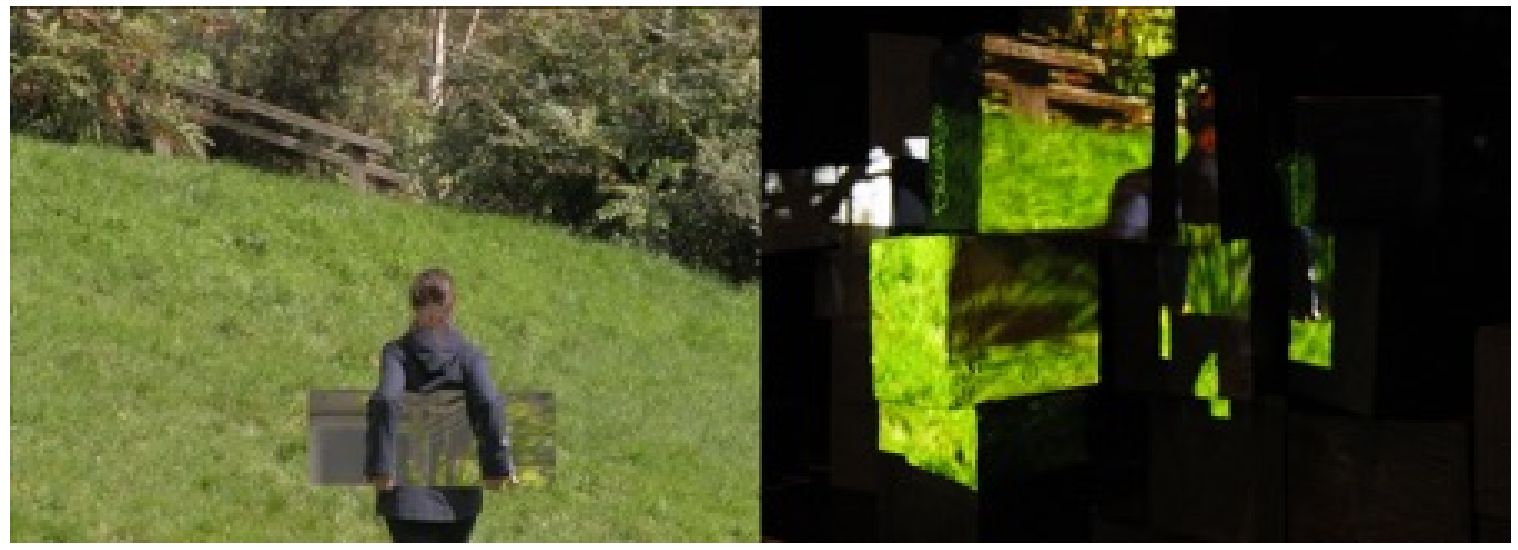

Sculpting the Image. Fillm still (left) and photo of the same still during Anarchitextures (right). Credit: Author

Anarchitextures 3 is a screen-based and intermedial 4 choreographic environment and event. It is influenced by Diapolyekran and other scenographic and technological experiments of Czech set designer Josef Svoboda whose moving-image constructions integrate filmic projections. Anarchitextures shares with the screen-based performances of Svoboda the way film and stage share the same space, but remain distinct.5 Svoboda's alterable architectures for the stage derive from modularitymobile compartments able to join in various combinations to form transformable 
spaces.6 The alteration of Svoboda's environments is based on mechanically conceived apparatuses, but the presentation and evolution of Anarchitextures depends on interaction and the authority that the spectator is given to transport and reposition the cardboard boxes; each of which carries the potential to be a screen under the projected light across the floor of the stage.

Svoboda's experimentations focused on "the relationship between the live and the filmic and the projected and the architectonic" 7 and I will similarly attempt to share my thoughts from three perspectives: the architectural, the choreographic, and the screenic:

- Architecture, entering the discourse on performative and temporal architecture, 8 is characterized by "action, interaction, temporality and adaptation" 9 and it appears as an ephemeral environment.

- Choreography opens a dialogue with the expanded notion of choreography, 10 which reconsiders movement beyond the mere arrangement of agile bodies in motion.

- Screenic refers to "the transformation of the filmic raw material during its processing by projection and, ... to the fact that what occurs on the screen is part of a more general phenomenon involving theatre space and spectatorship." 11 The anarchitextural filmic material has been projected into cardboard boxes covered with concrete-the architectural and predominant material of the streets and cities; the spaces of concentrated polyphony and diversity where political and social actions and conflicts may take place.

I have used the projected image and the screen to unite architecture and choreography into a choreographic environment and event placed inside a theatrical context. The black box theatre became a visual and participatory environment free from the conventions of visual art and conformed more to the rules of the dance world. 


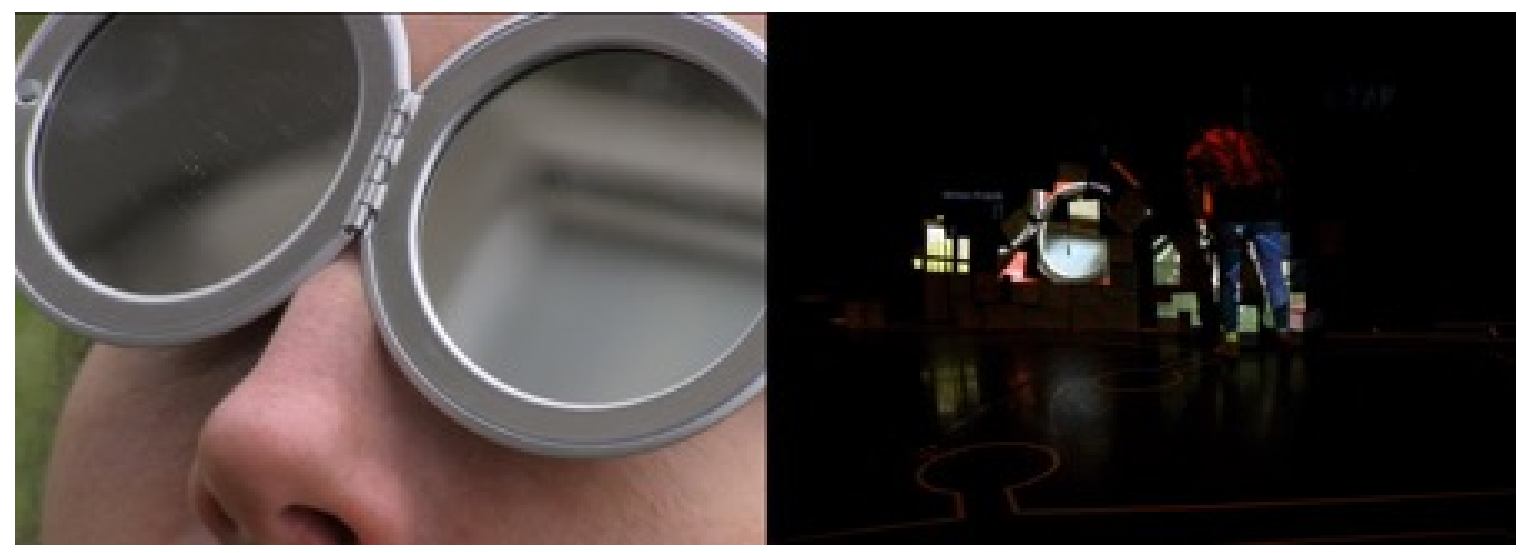

Building in process. Fillm still (left) and photo of the same still during Anarchitextures (right) Credit: Author

\section{Architectural Inputs}

The artist Alan Kaprow first used the word environment to frame his large multimedia works and distinguish them from installation art. The latter still nowadays refers to "the type of art into which the viewer physically enters, and which is often described as 'theatrical', 'immersive', or 'experiential'."12 Although both environment and installation share a dependence on sensually triggered viewership ${ }_{13}$ and an affinity with the site where they happen for a short life-span, Kaprow proposes that installation means, "very simply and literally, that somebody is taking something already fabricated or made, generally, and installing it." 14 Commenting on its distinction from installation-based art, he identifies the main characteristic of environment as that of "surround." 15 An environment, usually of room-size, is a "threedimensional work of art, often of temporary nature, which the viewer can enter." 16 For example, Rachael Whiteread's Embankment, 17 a massive sculpture of a large number of polyethylene white boxes stacked in piles, could be considered an installation of objects, but its monumental scale can also turn it into an environment.

The act of surrounding is key to my understanding of architecture and also connects architecture and environment. I perceive architecture as a structure bigger than my body in which I have the possibility to enter and feel protected by. Architect Bernard Tschumi writes: "Architecture is defined by the actions it witnesses as much as by the enclosure of its walls," 18 and architect Kate Macintosh presents the protective shelter as the fundamental element of architecture.19 In Anarchitextures, the limits of the ephemeral environment were manifest through the construction of walls made by cardboard boxes (covered in a thin layer of concrete) placed along the white-taped outline of the architectural plan of Robin Hood Gardens Estate. Anarchitextures was an attempt to create an ephemeral architectural environment, transformed into an event space by the intruding and interacting audience. 
Between 1981 and 1983, Tschumi defined architecture as the space of events, which is described as "both the space and what happens in it." 20 This concept makes architecture an experiential and live art performed by the "building and the people, the walls and the bodies." 21 An architect, similar to a film or theatre director, is the one who sets conditions22 and architecture is a stage to be performed on by actors of everyday life; a stage-set in which "radical choreographic ideas of space from dance and film could substitute for the power structure of plans, sections, and elevations." 23 The opportunity for pedestrian performances on the architectural and urban stage renders the space alive and transformable through the interaction of the user with architecture. Similarly, the theatrical stage where Anarchitextures took place is a space-or an architectural condition as Tschumi suggests-designed according to theatrical codes of spectatorship and conventions of staging that I adapted to the participatory project of Anarchitextures. The action of the audience to dislocate the cubes inside the ephemeral anarchitextural space, by attempting to recompose the configurations of the cardboard boxes, gradually unfixed the artwork-as-product and handed more artistic agency to the audience. The participatory actions to cross, transform, and appropriate the theatrical stage helped to turn both the anarchitextural environment and the surrounding black box theatre into event-spaces. Anarchitextures gradually evolved into an anarchic environment that slowly lost its pre-planned and pre-choreographed order through the actualization of the event, a social encounter that invites active and participatory spectatorship.

\section{Expanding the Notion of Choreography}

Choreography in an expanded view has been defined as the ability of an organism, a mechanism, a body, and a system to produce movement.24 Choreography as the disappearance of the subject which experiences dancing movement and the visibility of "the experience of movement itself, without the subject" 25 disconnects choreography from its direct association with the human bodies and turns attention into the ways movement is organized in space. In the Artificial Nature Series, Danish choreographer Mette Ingvartsen directly explores non-human choreography and performance. The Artificial Nature Project is a choreography for materials activated by human and non-human performers and Evaporated Landscapes is an artificial landscape in evolution made by ephemeral materials. Anarchitextures is in dialogue with these practices that approach broader concepts of mobility, evolution, spatial transition, and transformation as choreographic; it is not only an environment for moving inside or looking at, but also a transitioning space under the manipulation of the spectator. Movable screens, fabricated from boxes and arranged on the theatrical stage by the visitors, contributed to the continuous transformation of the ephemeral environment. The transformation of the anarchitextural landscape in time can be considered as movement, which occurs in the performative structure of Anarchitextures as a whole, and helps us to experience choreography as time. 
Besides the concept of spatial transformation perceived as movement, the moving and transported boxes-as-screens may also be converted into performers. The handfabricated screens have been anthropomorphized and architecture-morphized, as a result of the light projected onto them. Giuliana Bruno, researcher on the intersection between architecture, film, visual arts and media, refers to the transformative agent of projected light, and writes that "[t]he white film screen is like a blank wall on which the moving pictures of a life come to be inscribed. Etched on the surface, these experiential pictures, like film's own, change the very texture of the wall." 26 In Anarchitectures, cardboard boxes from a retail shop-"disconnected from utility and functionality through defamiliarization" 27 -were converted into individual or assembled screens that the projected light animates; the light changed their identity from pure and life-less geometric objects to screens carrying meaning and narrative. On the theatrical stage, the place where live performances usually occur, the movable boxes became the performers of the anarchitextural environment under the power of the projected light that philosopher Gilles Deleuze, speaking about the objective of the cinema in contrast to the theatre, refers to as the "luminous dust." 28

The construction of cubic sculptures can also be considered a choreographic task for visitors to alter the composition of the screens and, in turn, affect the appearance of the projected images. Under the active spectators, the moving images fragmented, got folded, or even disappeared. The input and responses of the active spectators to re-arrange the screenic configurations of the projected images transformed the choreographic environment into a choreographic event. Dance scholar Sophia Lycouris claims the use of choreographic environment 29 as an appropriate term to describe installation spaces that have emerged from choreographic thinking, and that require the audience to physically engage with them. Taking into account Kaprow's definition of surrounding environments and Tschumi's participatory character of event-spaces, I propose that the term choreographic event is more appropriate to describe environments which are, as Lycouris suggests, the outcome of a choreographic manifestation in space and the participants' active input. The choreographic event without the contribution of the mobile spectators and their response to the construction of screenic sculptures remains an intact and immersive choreographic environment. However, the identification of a choreographic outcome as event or environment is slippery and depends on the degree of audience participation and space activation that, in turn, define the degree of social engagement between choreographic work and spectator. Through this lens, a choreographic event is close to the notion of social choreography 30 which according to choreographer Ingvartsen is concerned with "the organisation of space, the organisation of a group in space and of its behavior." 31

I have defined the organisation and behaviour of the visitors inside the anarchitextural environment by the participatory and collaborative constructing and deconstructing 
of the anarchitextural environment and the quasi anarchic approach (in terms of lack of any specific choreographic instruction and control) of displacing, replacing, and repositioning the boxes-as-screens. In Anarchitextures, I juxtapose museums and galleries where projects' specifications, institutional conventions, and authorities usually encourage a fixed composition in space and prevent any haptic interaction with the exhibited work; I suggest to activate the sense of touch that is immanent in the social encounters with architecture and dance. Haptic, an experience activated by architecture, 32 refers to the ability to come into physical contact through the skin. 33 The surfaces of a building - such as the walls that surround us and the floor where we step with our feet-create a sensual effect 34 caused by the texture, density, and temperature of the architectural materials. The sense of touch activated through our skin and not only by our hands is also immanent in social dance, contact improvisation, or any type of partnering dance. According to choreographer Boris Charmatz, the co-instigator of La Musée de la Danse, dance is "permeable" 35 like the anarchitextural environment of this discourse. In Anarchitextures the audience manipulates the appearance and disappearance of the image, its fragmentation or completion. Touching, holding, and transporting the hand-fabricated screen to compose and recompose the projected images is part of building the haptic memory of the building-soon-to-be-demolished.

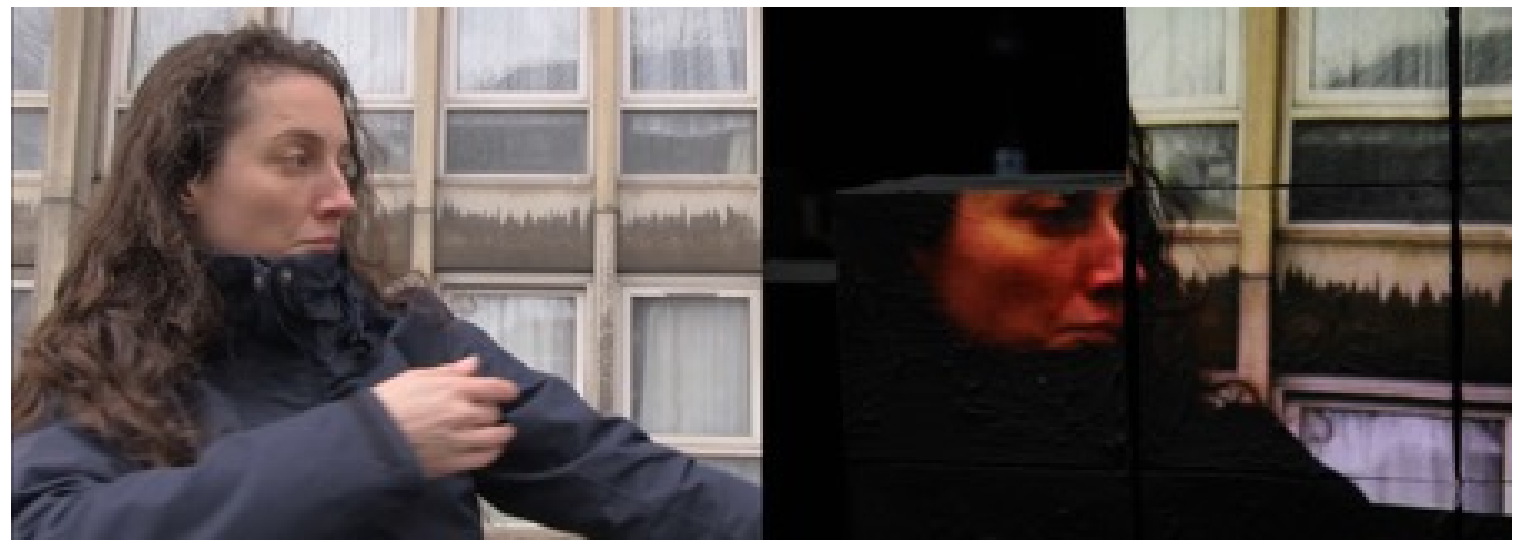

Katja Vaghi performing at the back side of the Eastern Block of Robin Hood Gardens Estate (left). Textured image during Anarchitextures (right). Credit: Author

\section{Screen Perspectives}

Haptic Screen Encounters

Screens-"a space of crossovers, in which the visual and the spatial arts come to be connected in textual materiality and surface tension," ${ }_{36}$-have been the focus of architects, film makers, and visual artists. For example, screens as architectural walls partition the internal spaces of the transparent Glass Pavilion (2006) in Toledo (OH) that is designed by the architectural group SANAA. Images that trace the family history of film director Chantal Akerman are projected on a tulle-as-screen that is part of her 
installation Walking Next to One's Shoelaces Inside an Empty Fridge, and Robert Irwin's installation Excursus: Homage to the Square "engages the forms of canvas, wall and screen in architectural inquiry." Irwin constructed rooms by scrim-walls where the color textures and hues of Joseph Albers' paintings are materialized in their surfaces through light. The viewers of the installation appear and disappear through the transparently fabricated walls and "like actors in a film, enter into a play of light and shadow, becoming shadows themselves." 37 In the above cases, screen is a wall, a surface, and a canvas which are all elements of architecture, film, and painting respectively. Therefore, screen is:

An object used to protect, obscure, or conceal, ... an architectural and sculptural apparatus used to separate or divide space in a process of exclusion or delimitation, ... a surface or a receptacle on which images are projected or displayed, ... a metaphorical term or a site of mediation involving a relationship between what is shown and what remains under cover.38

In the case of Anarchitextures, screens are modular units that were manipulated, assembled, and separated by the audience, and formed as walls with sculptural and volumetric depths. These assembled screens turned into three-dimensional surfaces expanding the depth, plasticity, and limits of a flat cinematic screen. The surfaces of the cardboard boxes had been painted with concrete that gave the projected image a textured layer and mostly concealed their mundane origins.

The concrete surface and canvas of the hand-fabricated screens offered to the moving image a skin, which helped to shift "our focus from the optic and toward a haptic materiality." 39 The surface of the screen, thus its outside, mediates between the projected image and the hand of the audience and "it is by way of such tangible, 'superficial' contact that we apprehend the art object and the space of art, turning contact into the communicative interface of a public intimacy." 40 Elisabeth Grosz, speaking about the operation of the outside, describes its ability to connect processes, events and series, creating a "plane of consistence or coexistence." 41 Therefore, I propose that the external cover-the skin of the fabricated screens-becomes the surface that connects visual and spatial arts through their disciplinary external membranes; the textured screen turns into a space for the exchange and coexistence of architecture as texture, film as surface, and dance as contact with another skin.

In the Skin of the Film Laura U. Marks, refers to the affect and synesthetic impact of viewing in all our senses, including the haptic, and defines haptic visuality as "the way vision itself can be tactile, as though one were touching a film with one's eyes." 42 Bruno's haptic materiality and Marks' haptic visuality refer to the difference between the skin of the screen and the skin of the moving image. Both perspectives play on the idea that the surface, the texture, and the medium on which the moving image is 
projected or screened matters, because it affects us differently. The mediation of the image by different surfaces is unique and every architectural texture and surface, such as the cinema screen or the brick, the metal, and the wood, absorbs the light of the moving image in different ways. In Anarchitextures, the texture of the building is not only depicted or represented on the screen, but it is sensed through the haptic encounter of the audience's hands with the dressed boxes-as-screens. Concrete, a very stable and strong architectural material when supported by steel, references the building of Robin Hood Gardens Estate. The concrete skin of the screen adds an additional layer of weathering - and the potential for a non-digital ruination-to the projected image. Therefore, the texture of the building merges with the skin of the moving image and the surface of screen; all of them reveal the passage of time.

Time is not only evident on the outer skin of architecture, but it is etched on the skins of the moving image and the screen-the surface that embodies "the relation of materiality to aesthetics, technology, and temporality." 43 By the end of the anarchitextural event, the concrete applied to the cardboard boxes has been almost pulverized, imprinting its grey dust on the floor and the skin of the hands of the audience. In this way, I think of Anarchitextures as an ephemeral gesture in space that gradually turns into rubble in the same way that derelict buildings fall under the power of excavating machines. Bruno, speaking about the essence of time imprinted on the screen, refers to Jane and Louise Wilson's A Free and Anonymous Monument an installation-archiving of the modern ruin of Victor Pasmore's Apollo Pavilion in the North East of England - that influenced me in the development of Anarchitextures. She writes that time is "impressed on other kinds of architecture-the translucent screens of moving-image installations. Pictures in motion write our modern history. They can be the living, moving testimony of the effects of duration. Moving images are modernity's ruins." 44 Bruno understands the screen of moving image to be a kind of architecture that captures the passing of time and I also propose that the texture and spatial arrangement of the boxes-as-screens contribute to an embodied archiving of the weathered buildings. The way that the anarchitextural screens were placed on the floor of the theatrical stage created free spaces for the mobile spectators to circulate among them as if inside the landscape of the Robin Hood Gardens Estate, and also able to touch the concrete texture of the building. Sporadically re-arranged pathways-among assembled screens formed into relief walls-were waiting to be crossed. 


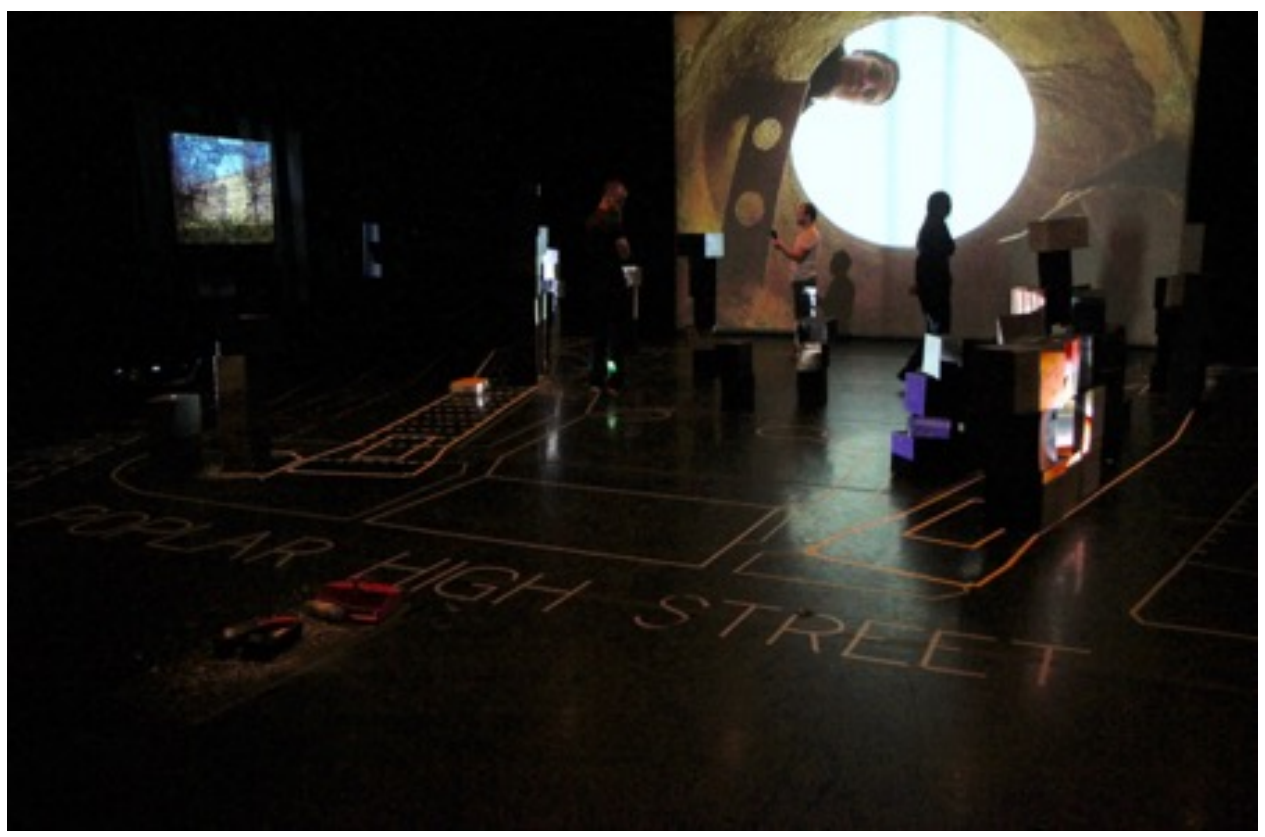

Diagram in space. Credit: Author

Walking as Montage. An active archive in process

In the field of architecture, the concept of path has been theorised by Le Corbusier, who called it promenade architecturale and defined it as the experience of walking through and in general circulating inside a building. The notion of path joins architecture and film "in a practice that engages seeing in relation to movement." 45 In contrast to Tschumi's approach to architecture as an opportunity for interaction through the notion of event-spaces, Le Corbusier gave to the experience of architecture an ocular attribute dependent on locomotion. He observed that architecture is "appreciated while on the move, with one's feet ...; while walking, moving from one place to another. ... A true architectural promenade [offers] constantly changing views, unexpected, at times surprising." 46 A promenade architecturale, otherwise a journey in space and time through a specific path, is what encourages mobile spectatorship and offers to architecture a dynamic conception which "overcomes the traditional notion of building as a still, tectonic construct." 47 As Bruno puts it, referring to the choreographed journey across the buildings of the Acropolis in Athens, "as we walk among (its) buildings, it is our legs that construct meaning." 48 Moving allows us to conceive the architectural space as a peripatetic and cinematographic practice. The elements of space are still, but our transportation among them creates memories and personal sequences of urban and architectural narratives.

Film director and theoretician Sergei Eisenstein stated that the mobile spectator on an architectural path "moved through a series of carefully disposed (architectural) 
phenomena which absorbed in order with his visual sense." 49 By the same token, Eisenstein identifies as path, and in particular the cinematic path, the mental ability of the mind to follow "a multiplicity of phenomena, far apart in time and space, gathered in a certain sequence into a single meaningful concept; and these diverse impressions pass in front of an immobile spectator." 50 This is the essence of Eisensteinian montage, which renders the screen the linking point of "various elements (fragments) of a phenomenon filmed in diverse dimensions, from diverse points of view and sides." 51 From this perspective, and as Eisenstein confirms, the cinematic technique of montage is inherited by the peripatetic experience of architecture, which provides to the spectator the possibility to create narratives of space in the imaginary screen of the mind. The cinematic path is a pre-defined and re-playable compression of space and time that unfolds in front of a static viewer, while the architectural path is a choreographed void that can always be revisited by a moving person. The speed, the pauses, and the order that the points of the path are linked to, may be composed in an improvisational and personal manner and in this way the architectural path is similar to the path as defined in dance.

Dancing is interwoven with the action of traversing immaterial space through a predefined or improvised path. In choreography, approached according to its etymology as "dance-writing," 52 the path is visualized as a drawn line usually found in dance notations and scores. For instance, from the first dance notations of RaoulAuger Feuillet to Yvonne Rainer's floor plans for Trio B, the flow of movement in space is indicated by a trace drawn on the paper. Path and trace are both imaginative forces for moving in space through time. Both are represented as a line, but they differ ontologically because one refers to the past and the other to the future. Trace is "any enduring mark left in or on a solid surface by a continuous movement." 53 Path is a soliciting of perambulation, a route-finding device through a mapped space. The poetic drawings of Anne Teresa De Keersmaeker on the sand during the violin phase of Fase, the bodily drawings of Trisha Brown (It's a Draw/Live Feed), and the digital visualisations of the trace in William Forsythe's choreographic objects (Improvisation Technologies, Synchronous Objects), witness dance's concern for the inscription, capture, materialisation, transformation, and interpretation of the trace and path into movement, and vice versa. In both architecture and dance, the trace as an archive of motion and transition can suggest a path that is waiting to be crossed again.

The triadic intersection of the path in architecture, film, and choreography distinguish the concept of montage in space inside a choreographic environment from montage for screen. While the latter requires a static receiver of moving-images, the mobile spectator in a choreographic environment is engaged in an active editing of space and is potentially involved in the production of an event-space; a dynamic transformation of space. During Anarchitextures the moving spectator is the editor who creates the montage of the moving images from Robin Hood Gardens Estate by walking in space, 
mentally and manually putting the pieces of the 'puzzle' together. The spectatorwanderer is the one who gains an understanding of the building (Robin Hood Gardens Estate) by navigating in space, moving, touching, and re-arranging its components. The wanderer constructs a non-linear narrative out of the architectural traces, the sculptural assemblies of cubes, the optional audio archives, and the textured images of the fragmentary and dramaturgically constructed anarchitextural environment. The mobile spectator, who experiences locomotive, ocular, and haptic senses, becomes an active participant who at the end enacts the work and builds an embodied and multisensory memory of architecture.

\section{Expanding the Screendance Field}

In this writing, I have sought to examine the transformation of space, the shared artistic authorship, the haptic interaction with the screens, and the navigation in space as the basic participatory aspects of the screen-based project Anarchitextures. As Anarchitextures was presented inside a theatrical context, I have attempted to rethink the limits between stage and auditorium and to propose the theatre as a revitalized public space for the dialogue between architecture, choreography, and moving-image through the creation of choreographic events-choreographed conditions that give permission to the audience to gradually transform the work and the space using the elements of the work. I have also written about the immersive and experiential character of architecture, the permeability of dance, the haptic visuality of film, and the way that they might be present together on the materiality, texture, and transportability of the modular screen. Spectatorship based on the haptic materiality of the screen and mobilized inside choreographic paths produces experiences associated with how we engage with architecture through haptic and ocular senses. Montage in space-an invitation towards the audience to apply basic tools of film editing, such as assembling and cutting for the production of social space-provided some views on challenging fixed and passive spectatorship. Assemblage and cut were applied to the sculptural compositions of the screens that in turn transformed the space and the composition of the moving-images.

Furthermore, I have suggested that the design of space, either of a building or an installation, and an environment, is deeply choreographic as it also concerns paths for moving journeys. For this last reason, I wish to propose that choreographic aspects of visual installations push such environments into the current discourse on expanding the definition of screendance. 54

Screendance is gradually expanding and striving to emancipate dance from its strict association with the trained body. For example, Harmony Bench's hyperdance "recuperates performance for the screen and positions the computer user not only as a viewer/spectator, but as a performer and even co-choreographer." 55 Claudia Kappenberg's Screendance Effort Graph maps the field of screendance "without 
prescribing aesthetic forms or limiting the range of possibilities." ${ }_{56}$ Anna Heighway's notion of radical screendance sheds light on screendances in the absence of the moving body and in the presence of anything "kinetically driven." 57 Such radicalities mirror the practices of expanded choreography and expanded cinema. I propose that we consider screen-based installations-deriving from choreographic thinking, providing choreographic experiences, and containing choreographic principles-to be expanded screendance; that visual installations, environments, and events could also be characterized as screendance installations, environments, and events.58

Screendance environments and events demand an active spectator. Thus, spectatorship is less concerned with seeing, but with engaging full body immersion, participation, and social interaction, which may not only be limited to the process of making screendance, but expanded into the way that screendance arrives to an audience. The way that space between and around viewers may be organized becomes important for screendance makers and curators as long as screendance curatorship is aligned with expanded choreographic practices. The fact that every surface can turn into a screen, and therefore every space can be transformed under the power of the projected light can enrich the possibilities of the screendance-asevent. Events turn attention to what happens in the spaces between bodies, and between bodies and architecture, and can pave the way for the display of screendance as an event with social parameters-as an expanded choreographic action that may transform and appropriate spaces and spectators' experiences.

\section{Biography}

Ariadne Mikou is an interdisciplinary dance artist, movement educator and emergent scholar from Greece. After graduating from the School of Architecture at Aristotle University of Thessaloniki (GR) she moved to USA in order to pursue a Master of Fine Arts in Dance from The Ohio State University with support from the State Scholarship Foundation of Greece. She is currently based in London where she is concluding her fully-funded practice-as-research $\mathrm{PhD}$ at the University of Roehampton having as focus the spatio-corporeal and social intersections of event-oriented artistic practices that include architecture, choreography and the moving-image. In parallel with curating exchanges between artists, her practice includes making and writing about works created for the screen, installations and mediated performances.

Email:alosidne@gmail.com

Website: www.amikou.com 


\section{Notes}

1 Douglas Rosenberg, Screendance, 16.

2 Anarchitextures was realized with the contribution of Katja Vaghi (video performance); Tom Medwell (camera); futuremellon/not yet art (production); Michael Toon (technical management); Chelsea Rolfe, Emily Sadler, Bruce Sharp, Jenny Whittaker (technical assistance).

3 The name Anarchitextures derives from the anagrammatic alteration of Anarchitecture, an art collective that was initially formed in 1973 by Gordon MattaClark and other artists in order to "think about the transitional, or transpositional, in architectural practice" (Pamela M. Lee, Objects to Be Destroyed,104). Matta-Clark has been well known for his violent interventions in pre-demolished buildings and his vanishing anarchitectural actions revealed the inside of architecture to the outside through cutting parts of derelict buildings. In a similar way, Anarchitextures bring the insides of the disciplines into view and exchange with each other. Other contemporary practices that mirror Matta-Clark's logic of cut is the work of Sara Oppenheimer whose sculptures cut or withdraw part of existing spaces.

4 Dominique Chateau and Jose Moure write in 2016 that "Intermediality is a key concept introduced by historians having realized that traces of other media are to be found in movies. It is also reversible: traces of movies are to be found in other media." Chateau and Moure, Screen, 21.

${ }_{5}$ See Chris Salter, Entangled. 152.

6 Idem, 50.

7 Idem, 153.

8 See Kolarevic and Malkawi, Peformative Architecture, and Salter.

${ }_{9}$ Salter, 84.

10 Expanded Choreography. Xavier Le Roy, Macba, 2012.

${ }_{11}$ Château \& Moure, 16.

${ }_{12}$ Claire Bishop, Installation Art, 6.

13 Ibid. Bishop writes that Installation art "presupposes an embodied viewer whose senses of touch, smell and sound are as heightened as their sense of vision."

${ }_{14}$ Alan Kaprow and John Held, An Interview with Alan Kaprow.

15 Ibid.

${ }_{16}$ Edward Lucie-Smith cited in Julie Reiss, From Margin to Center, 12.

17 Embankment was commissioned for Tate Modern's Turbine Hall.

18 Bernard Tschumi, quoted in Rachel Sara and Alice Sara, "Between Dance and Architecture," 62.

${ }_{19}$ Utopia London.

20 Tschumi, et al, "Performance/Architecture," 53.

21 Sara and Sara, 63.

${ }_{22}$ See Tschumi, "The Architecture of the Event."

${ }_{23}$ Salter, 85.

24 See Rudi Laermans, "'Dance in General."' 
25 Bojana Bauer, "The Makings of," 15.

${ }_{26}$ Giouliana Bruno, Atlas of Emotion, 105.

27 André Lepecki quoted in Erin Brannigan, "Dance and the Gallery," 14.

28 He writes that cinema "spreads an 'experimental night' or a white space over us; it works with 'dancing seeds' and a 'luminous dust'; it affects the visible with a fundamental disturbance, and the world with a suspension, which contradicts all natural perception." Gilles Deleuze, Cinema 2, 201.

${ }_{29}$ See Sophia Lycouris, "Choreographing Environments."

30 See Andrew Hewitt, Social Choreography, and Bojana Cvejic and Ana Vujanovic, TkH Journal Special Issue on Social Choreography.

31 Mette Ingvartsen, "Soft Choreography," 68.

32 Teachers of architectural design Kent Bloomer and Charles Moore refer to the haptic systems that allow to perceive architecture through our bodies. 1977. Architect and urban designer Steen Eiler Rasmussen describes the textural effects of architecture. 1964. Juhani Pallasmaa writes about how the eyes of the skin see architecture. 2005 Christian Norberg-Schulz examines the phenomenological encounters with architecture 1980.

33 Bruno, Atlas of Emotion, 6.

34 Architect Peter Zumthor writes about architecture that it is perceived as "a bodily mass, a membrane, a fabric, a kind of covering, cloth, velvet, silk, all around me ... A body that can touch me." Atmospheres, 23.

35 Jérôme Bel and Charmatz, "Jérôme Bel and Boris Charmatz," 236-7.

${ }_{36}$ Bruno, Surface, 7.

37 Idem, 74.

${ }_{38}$ Château \& Moure, 15.

39 Bruno, Surface, 3.

$40 \mathrm{lbid}$.

${ }_{41}$ Elizabeth Grosz writes: "[t]he interiority of (these) series is of less interest than the way they are capable of being aligned to connect, creating their plane of consistence or coexistence, which is made possible only through the operations of this outside." Space, Time and Perversion, 134.

42 Laura U. Marks, "The Skin and the Screen," 11.

43 lbid.

44 Bruno, Public Intimacy, 82.

45 Bruno, Atlas of Emotion, 58.

46 Le Corbusier quoted in ibid.

47 Idem, 57.

$48 \mathrm{Idem}, 56$. The buildings of Acropolis in Athens are also the case study of Eisenman's treatise Montage and Architecture (ca 1938).

${ }_{49}$ Sergei Eisenstein quoted in Micheal Dear, "Between Architecture and Film," 11.

50 Eisenstein, "Montage and Architecture," 116.

51 Eisenstein quoted in Yve Alain Bois and M. Glenny, "Introduction," 111. 
52 Susan Leigh Foster, "The word 'choreography' derives from two Greek words, choreia, the synthesis of dance, rhythm, and vocal harmony manifest in the Greek chorus; and graph, the act of writing." Choreographing Emphathy, 16.

53 Tim Ingold, Lines, 43.

54 See for example Harmony Bench, "Hyperdance"; Claudia Kappenberg, "Does Screendance need to look like dance?"; Rosenberg Screendance; Anna Heighway, "Understanding the 'Dance'"; Andrea Davidson, "Extending the Discourse of Screendance."

55 Bench, 89.

56 Kappenberg, 103.

${ }_{57}$ Heighway, 45.

${ }_{58}$ For instance, the screenic variations of the multi-channel installation Total Recall by Gretchen Bender is clearly based on rhythmic changes of visual images that could be considered equally choreographic. In her attempt to deconstruct the totality of television as a medium of consumerism, Bender uses synchronization and juxtaposition of moving images across different screens. In turn, this technique follows the paradigm of a rhythmic mosaic image on a single channel screen.

\section{References}

A Free and Anonymous Monument. Art. Jane \& Louise Wilson. London: Baltic Centre for Contemporary Art, 2003. Installation.

Anarchitextures. Dir. Ariadne Mikou. London: Michaelis Theatre, 2016. Installation.

Artificial Nature Series. Chor. Mette Ingvartsen. 2009-2012. Performance Series.

Bauer, Bojana. "The Makings of ... Production and Practice of the Self in Choreography: The Case of Vera Mantero and Guests." Performance Research. 13:1 (2008): 15-22.

https://doi.org/10.1080/13528160802465425

Bel, Jérôme and Boris Charmatz. "Jérôme Bel and Boris Charmatz: Emails 2009-2010." In Noémie Solomon (Ed.) Danse: An Anthology. Dijon, France: Les Presses du Réel, 2014: 241-250.

Bench, Harmony. "Hyperdance: Dance Onscreen, Dance Online. Exploring the Internet as a Site for Dance Performance." In Jessica Vokoun (Ed.) Screendance: The State of the Art Proceedings. Durham, NC: Duke University, 2006: 89-95.

Bishop, Claire. Installation Art. A Critical History. London: Tate Publishing, 2005. 
Bloomer, Kent. C. and Charles Moore. Body, Memory and Architecture. New Haven aand London: Yale University Press, 1977.

Bois, Yve Alain and M. Glenny. "Introduction." Assemblage. 10 (1989): 110-115.

Brannigan, Erin. "Dance and the Gallery: Curation as Revision." Dance Research Journal 47.1 (2015): 3-25. https://doi.org/10.1017/S0149767715000054

Bruno, Giuliana. Atlas of Emotion: Journeys in Art, Architecture, and Film. London and New York: Verso, 2002.

----. Public Intimacy. Architecture and the Visual Arts. Cambridge and London: The MIT Press, 2007.

----. Surface. Matters of Aesthetics, Materiality, and Media. Chicago: University of Chicago Press, 2014.

Chateau, Dominique. and Jose Moure. Screen. From Materiality to Spectatorship - A

Historical and Theoretical Reassessment. Amsterdam: Amsterdam University Press, 2016.

Cvejic, Bojana and Ana Vujanovic (Eds.) TkH Journal Special Issue on Social

Choreography 21 (2013). http://www.tkh-generator.net/portfolio/tkh-21-socialchoreography/

Davidson, Andrea. "Extending the Discourse of Screendance." In Doug Rosenberg (Ed.) The Oxford Handbook of Screendance Studies. New York: Oxford University Press, 2016: 389-419.

Dear, Michael. "Between Architecture and Film." Architecture and Film Architectural Design. 64.11/12 (1994): 9-15.

Deleuze, Gilles. Cinema 2: The Time-Image. Translated by Hugh Tomlinson and Robert Galeta. Minneapolis: University of Minnesota Press, 1989.

Eisenstein, Sergei Mikhailovich. "Montage and Architecture." Assemblage. 10 (ca 1938): 110-115.

Embankment. Rachael Whiteread. London: Tate Modern, 2005. Installation.

Excursus: Homage to the Square. Robert Irwin. New York: Dia Center for the Arts, 1998. Installation.

Fase. Chor. Anne Teresa De Keersmaeker. 2002. DVD.

Forsythe, William. "Choreographic Objects." 2008

http://www.williamforsythe.de/essay.html 
Foster, Susan. Choreographing Empathy: Kinesthesia in Performance. London:

Routledge. 2011

Glass Pavillion. Arch. SANAA. Toledo (OH). 2006. Building.

Grosz, Elizabeth. Space, Time and Perversion: Essays on the Politics of Bodies. New York and London: Routledge, 1995.

Heighway, Anna. "Understanding the 'Dance' In Radical Screendance." International Journal of Screendance 4 (2014): 44-62. https://doi.org/10.18061/ijsd.v4i0.4530

Hewitt, Andrew. Social Choreography: Ideology as Perfmance in Dance and Everyday Movement. Durham: Duke University Press, 2005.

https://doi.org/10.1215/9780822386582

Improvisation Technologies Dir. William Forsythe. 1994. CD-ROM.

Ingold, Tim. Lines: A Brief History. London: Routledge. 2007

Ingvartsen, Mette. "Soft Choreography." TkH Journal Special Issue on Social Choreography 21 (2013): 68. http://www.tkh-generator.net/portfolio/tkh-21-socialchoreography/

It's a Draw/Live Feed. Chor. Trisha Brown. Minneapolis: Walker Art Center, 2008.

Drawing \& Performance.

Kaprow, Alan and John Held. An Interview with Alan Kaprow. 1988.

http://www.ubu.com/papers/kaprow_held_interview.html

Kappenberg, Claudia "Does Screendance need to look like dance?" International Journal of Performance Arts and Digital Media. 5.2-3 (2009): 89-105.

Kolarevic, Branko and Ali. M. Malkawi. Peformative Architecture: Beyond Instrumentality. New York and London: Spon Press. 2005

Laboratoire du Geste. Expanded Choreography. Situations, Movements, Objects. http://www.laboratoiredugeste.com/spip.php?article583

Laermans, Rudi. "'Dance in General' or Choreographing the Public, Making Assemblages." Performance Research 13:1 (2008): 7-14.

https://doi.org/10.1080/13528160802465417

La Musée de la Danse. Dir. Boris Charmatz. Rennes: Centre Chorégraphique National de Rennes et de Bretagne. 
Lee, Pamela M. Objects to Be Destroyed. The Work of Gordon Matta-Clark. Cambridge \& London: The MIT Press. 2000.

Lycouris, Sophia. "Choreographing Environments: New Technologies and MovementRelated Artistic Work." In Jo Butterworth and Liesbeth Wildschut (Eds.) Contemporary Choreography. A Critical Reader. Abingdon: Routledge. 2009. 346-361.

Marks, Laura. U. "The Skin and the Screen - A Dialogue." In Dominque Chateau and Jose Moure (Eds.) Screens: From Materiality to Spectatorship - A Historical and Theoretical Reassessment. Amsterdam: Amsterdam University Press, 2016. 258-263.

Norberg-Schulz, Christian. Genious Loci: Towards a Phenomenology of Architecture. London: Academy Editions, 1980.

Pallasmaa, Juhani. The Eyes of the Skin: Architecture and the Senses. Chichester: Wiley Academy, 2005.

Rasmussen, Steen Eiler. Experiencing Architecture. (2nd ed.) Cambridge, MA: The MIT Press, 2000.

Reiss, Julie. H. From Margin to Center. The Spaces of Installation Art. Cambridge and London: The MIT Press, 1999.

Rosenberg, Douglas. Screendance: Inscribing the Ephemeral Image. New York and Oxford: Oxford University Press, 2012.

https://doi.org/10.1093/acprof:oso/9780199772612.001.0001

Sara, Rachel and Alice Sara. "Between Dance and Architecture." In V. Hunter (Ed.) Moving Sites. Investigating Site-Specific Dance Performance. New York: Routledge, 2015. 62-78.

Salter, Chris. Entangled. Technology and the Transformation of Performance. Cambridge and London: The MIT Press, 2010. https://doi.org/10.7551/mitpress/9780262195881.001.0001

Synchronous Objects. Dir. William Forsythe, Maria Palazzi, and Norah Zuniga Shaw. 2009. http://synchronousobjects.osu.edu/

Total Recall. Gretchen Bender. Liverpool: Tate, 2014 [1987]. Installation.

Tschumi, Bernard. "The Architecture of the Event." Architectural Design 61.1-2 (1992): 24-27.

----. Architecture \& Disjunction. Cambridge and London: The MIT Press, 1996. 
Tschumi, Bernard, Dorita Hannah, and Omar Khan. "Performance/Architecture: An Interview with Bernard Tschumi." Journal of Architectural Education 61.4 (2008): 52-58. https://doi.org/10.1111/j.1531-314X.2008.00187.x

Utopia London. Dir. Tom Cordell. 2010. DVD.

Walking Next to One's Shoelaces Inside an Empty Fridge. Chantal Akerman. Berlin: Jewish Museum Berlin, 2007. Installation.

Zumthor, Peter Atmospheres: Architectural Environments Surrounding Objects. Basel: Birkhauser, 2006. 